https://doi.org/10.31470/2706-7904-2021-16-113-127

\title{
НА ЩО СПРОМОЖНА ГЕНЕРАТИВНА СИСТЕМА ЛЮДИНИ?
}

What is the Human Generative System Capable of?

\section{Larysa Kalmykova}

Dr. Sc. in Psychology, Professor

Hryhorii Skovoroda University in Pereiaslav (Ukraine)

klo377@ukr.net

https://orcid.org/0000-0002-7538-2635

\section{Nataliia Kharchenko}

Dr. Sc. in Psychology, Professor

Hryhorii Skovoroda University in Pereiaslav (Ukraine)

kharchenko.nataliia.v@gmail.com

https://orcid.org/0000-0002-9958-5226

\section{Inna Mysan}

Ph.D. in Pedagogy, Assistant Professor

Hryhorii Skovoroda University in Pereiaslav (Ukraine)

mysan.iv79@gmail.com

https://orcid.org/0000-0001-9416-4484

\begin{abstract}
Absrtact
The article presents a new view on the generative system of man, highlights his ability not only to provide the mastery and possession of language (L1, L2), to generate numerical statements, but also to use language means in their various functions (primary and secondary), depending on the communicative and cognitive needs, situations of communication of his life activity.
\end{abstract}

Key words: generation, mastering the functions of languages, functionally centered ethnolanguages.

\section{Вступ \\ Introduction}

Як відомо класифікація мов світу традиційно здійснюється за певними таксономічними рубриками згідно з кількістю тих суспільних функцій, які виконуються ними в суспільстві. Ця класифікація отримала назву «функціонально- 
типологічна». Ми пропонуємо здійснювати класифікацію мов світу за іншими підставами, спираючись на генеративну систему людини. Тоді основою класифікації стає мовна компетенція і мовленнєва компетентність людини, а підставою для групування мов стають індивідуальні, суб'єктні, особистісні здатності суб'єкта мовлення використовувати ту чи ту національну мову в їх різних функціях у своїй мовленнєвій поведінці. Психолінгвістичні підстави для класифікації мов світу - це перспективна новація в науці, яка створює передумови для реалізації гуманітарних питань зручного й комфортного використання людиною різних мов в їх поліфункціонально-центрованих функціях задля: (а) досягнення індивідуально значущих для неї конкретних комунікативно-мовленнєвих цілей і реалізації іiі певних мовних цінностей; (б) максимальної вербальної гармонізації планетарного соціуму, його еволюції; (в) досягнення «доцільної комунікації» (Леонтьев, 2003); (г) толерантного забезпечення реалізації мовних прав і свобод кожної людини. Це стосується як суб'єктів усього сучасного полілінгвального світу, так і суб'єктів окремого, особливо поліетнічного й полікультурного, суспільства.

Відповідно до запропонованої концепції ми подаємо погляд на мову людини як на біопсихолінгвосоціальне явище і 3 функціонально-психолінгвістичних позицій вибираємо підстави для класифікації етномов за їх функціями в іï індивідуальній мовленнєвій практиці. 3 огляду на висловлене мовна здатність людини - це не тільки iii спроможність породжувати мовлення за імпліцитно засвоєними правилами граматики, а й здібність використовувати мови в різних функціях, зокрема функціях рідної мови, державної мови, офіційної мови, національної мови, регіональної мови; мови національних меншин, міжетнічної мови, міжнародної мови, ділової мови, мови міжнаціонального спілкування, мови міжнародного спілкування; мови науки; мови спеціальності та ін. Отже, завдяки мовній компетенції кожна людина здатна виконувати багатоманітні функції етномов, реалізовувати їх в мовленнєвій активності відповідно до завдань життєдіяльності. Мови світу, які виконують багатоманітні функції в дискурсі кожного індивіда, потребують оформлення в самостійні психолінгвістичні поняття.

Такими поняттями є: (1) «первинно функціональні мови» та (2) «вторинно функціональні мови» (Калмикова, Харченко \& Мисан, 2021). Ми пропонуємо використовувати термін «первинно- і вторинно функціональні мови» для номінації та групування різних назв мов (абстрагуючись від конкретних етнічних мов) за їх функціональною роллю в комунікативно-мовленнєвій діяльності окремої людини. Номінації різних видів первинно- і вторинно функціональних мов презентують провідні для них функції. Деякі види функціонально-центрованих мов, окрім провідних для них функцій, є ще й багато- і різнофункціональними. Ми об’єднуємо їх 
в одну типологічну групу за вищими психічними функціями, що доконуються завдяки мовній компетенції і мовленнєвій компетентності людини в генеративній системі іiі суб’єктів засобами індивідуальної мови незалежно від конкретної етнічної мови. Первинно функціональні мови - це мови, які за станом еволюції в онтогенезі, філогенезі та соціогенезі виконують у мовленні членів того чи того суспільства лише когнітивні, комунікативні та пов'язані 3 ними інші функції, необхідні для спілкування, розвитку та повноцінного існування людей у соціумі в межах певного етносу. Вторинно функціональні мови, здебільшого, багатофункціональні. Вони за станом розвиненості спроможні виконувати складніші функції.

Отже, мета сmammi - представити новий підхід до класифікації мов світу, яка грунтується на психолінгвістичних засадах, продемонструвати можливості мовної здібності людини не тільки володіти граматикою національних мов, а й використовувати їх поліфункціонально в процесі генерації мовлення.

\section{Методи дослідження Methods of the Research}

У дослідженні використовувалися такі методи дослідження: (а) системний аналіз літератури й виділення підстав для класифікації національних мов світу; (б) функціональний аналіз мов світу; (в) класифікація етномов за функціями, які вони виконують у мовленні їх носіїв; (г) опис ролі функцірнально-центрованих мов в генеративній системі людини; (д) узагальнення результатів.

\section{Результати \\ Results}

Існує значна кількість функціонально-центрованих мов, які поділяються на природні й штучні.

Розмовні мови є живими мовами комунікації і належать певній мовній спільноті. Для них має значення факт їх вживання в даний час, а не те, скільки за чисельністю людей користується ними. Це природні звукові мови, або натуральні мови - мови спілкування на відміну від формальних мов та інших знакових систем. Їхня граматика й словник визначаються лише практикою застосування i не завжди формально зафіксовані. Вони ніколи не створюються цілеспрямовано, а є справжніми, оригінальними. Натуральні мови називають звуковими через їх стихійне виникнення як системи дискретних звукових кодів, що постійно розвиваються. Звук у 
натуральних мовах виступає «матерією» мови, є цеглинами, 3 яких утворюється функціонуюча в усному мовленні людини мова спілкування.

Штучні мови створюються в синтетичний спосіб для передавання будь-якої специфічної інформації (мови програмування, нотна грамота, азбука Морзе, цифровані системи, есперанто, жаргон та ін.). Деякі мови знаходяться на перетині штучності й природності (ретрогерманська мова у Швейцарії, чеська мова та іврит відроджені мови).

На противагу натуральній (звуковій) мові письмова мова є, в певному сенсі, штучною мовою, своєрідним зображувальним кодом вже існуючих у свідомості людини живих звукових кодів. Отже, звукова мова є першим кодом - вербальним еквівалентом предметів і явищ, зв’язків між ними, замінником існуючих подій i ситуацій, а писемна мова - другим кодом, тобто кодом кодів.

Штучні мови - це спеціалізовані мови, в яких мовні одиниці були спеціально розроблені для втілення певних цілей. Цілеспрямованість цих мов відрізняє їх від природних мов. Штучні мови ще називають несправжніми мовами. Існує більше тисячі таких мов. Причини їх створення наступні: полегшення людського спілкування, надання художній літературі додаткового реалізму, лінгвістичні експерименти, комунікація у вигаданому світі, мовні ігри тощо. Вираз «штучна мова» використовується і для номінації планових мов для спілкування людей, щоб уникнути зневажливого відтінку слова «штучний», який є в деяких мовах.

Розрізняють такі види штучних мов: (а) мови програмування і комп'ютерні мови; (б) інформаційні мови; (в) формалізовані мови; (г) міжнародні допоміжні мови (планові); (д) мови неіснуючих народів; (е) мови для спілкування 3 позаземним розумом; (є) філософські і логічні мови (ложбан, токинона, ілакт); (ж) допоміжні мови (есперанто, міжслов'янська мова, Лінгва франка та ін.). Найпоширенішими у світі визнані такі штучні мови, як: есперанто, інтерлінгва, волапюк, логлан, сольресоль, іфкуіль, токіпона, клінгенська мова, теги.

До первинно функціональних видів мов відносимо: регіональну мову, рідну мову, міжетнічну мову, мову національних меншин, національну мову, материнську мову, успадковану мову, етнічну мову, першу мову. Вони реалізовують переважно функції комунікації і пізнання, хоча мають і свої особливі, властиві тільки кожному конкретному виду мови, функції.

Базовим психолінгвістичним поняттям у системі первинних функціонально центрованих мов, властивих дитині, є поняття «перша мова - L1». Оволодіння функціями першої мови більшістю дослідників дитячої мовної здатності тлумачяться як первинними, які дитина опановує з раннього дитинства для комунікації й пізнання 
без цілеспрямованого навчання, знаходячись у відповідному мовному середовищі (Цейтлин, 2000; Калмикова, 2018; Ушакова, 2004).

В онтогенезі функціонально близькі функціям першої мови функції рідної мови. О. Леонтьєв (Леонтьев, 2003: 218) зауважує: “рідна мова в психолінгвістичному сенсі - це та мова, якою дитина вимовила свої перші слова». Вони свідчить про те, що в неї в корі головного мозку вперше почали виформовуватися засобами цієї мови перші нейронні зв’язки і нейронні мережі. О. Козінцев пише: «... мова ніби блукає по корі, вибираючи, залежно від обставин, де ій «укорінитися». У маленьких дітей утрата навіть більшої частини лівої півкулі не перешкоджає засвоєнню мови» (Козинцев, 2004: 41-42).

Рідна мова дитини не завжди співпадає 3 національністю пї батьків. Неодноразові i навіть закономірні для сучасного міграційного світу приклади засвоєння дітьми мови в родинах, де батьки є представниками різних національностей $\mathrm{i}$ носіями різних етнічних мов. О. Козінцев експериментально довів, що: «у дітей дві різні мови - рідна і друга, які вважають за краще не перетинатися в корі, а вибирають або різні ділянки однієї півкулі, або різні півкулі. І не лише кори головного мозку. Роль підкірки в мовній функції важливіша, ніж здавалося раніше» (Козинцев, 2004: 30).

Описані й такі випадки, коли через невігластво дорослих діти потрапляли в лігво вовків із народження. Вони переймали всі голосові реакції тварин, а коли їх знаходили й повертали в соціум, вони були неспроможні через втрату сензитивного в онтогенезі періоду засвоїти рідну мову на рівні своїх однолітків, залишаючись усе подальше своє життя нездатними до повноцінного вербального спілкування. Ці факти підтверджують роль як біологічних, так і соціальних факторів в еволюції мови дитини.

Коли рідна мова за національною ознакою іiі носія не співпадає 3 державною мовою, тоді в державах із незбалансованою мовною ситуацією, яка характеризується неоднаковим ступенем виконання мовами суспільних та індивідуальних мовних функцій, нерідко виникають суперечки між носіями національних мов і політиками щодо ієрархічного розподілу мов та їх функціонування. Носії національних мов у таких випадках вбачають обмеження свої мовних прав i свобод. Iз психолінгвістичної точки зору дитині, яка з народження розмовляла рідною мовою, дуже важко в школі відразу навчатися державної або офіційної мови. На це $\epsilon$ природні психофізіологічні, нейролінгвістичні причини, а саме: несформованість у дитини потрібних для користування цими мовами нейронних мереж, багаторівневої організації та сенсорної корекції динамічних мовленнєвих процесів (Калмикова, Харченко \& Мисан, 2021).

Розмежовуючи рідну і першу мову, Н.Б. Вахтін і Є.В. Головко у своїй праці спеціально підкреслюють, що $є$ випадки, коли рідна мова у дитини (за певних 
обставин) згасає, а на перший план виходить мова, засвоєна паралельно або пізніше: «материнська мова - не обов'язково рідна, а рідна - не обов'язково перша» (Вахтин \& Головко, 2004: 46). Дослідження О. Козінцева підтверджують це положення: «при ураженнях полосатого тіла, рідна мова може зруйнуватися, а засвоєна пізніше зберегтися» (Козинцев, 2004: 35).

Рідну мову дитини називають ще й материнською мовою, оскільки вона інтимно пов'язана з матір'ю. Материнська мова не тільки «близька» дитині та перспективна для їі психічного розвитку, а й функціонально необхідна їй. Своєрідна «мова нянь» $є$ адаптивною до потреб дитини в комунікації з матусею й близькими, оточуючими іiі людьми. Людина, яка опікується проблемами розвитку мовлення 1-6місячної дитини, керуючись материнським інстинктом, говорить 3 нею лагідно, використовуючи зменшувано-пестливі суфікси, проспівує голосні звуки тощо. Материнською мовою називають і таку мову, що засвоєна в дитинстві і не обов'язково від матері, або батька. Таких мов може бути кілька, проте одна 3 них обов'язково вважатиметься першою. Деякі з них можуть бути втрачені до дорослого віку.

Мови, які позначаються термінами «материнська мова», «рідна мова», «перша мова» на перший погляд здаються очевидними, загальновідомими, і навіть тотожними. Насправді, ці поняття, як правило, не співпадають.

Спорідненим із поняттям «рідна мова» і близькими за змістом до нього функціонально є поняття «природна мова», яка трактується як мова, що використовується насамперед для спілкування людей. Вона не створюється цілеспрямовано; іiї функції - комунікативна і когнітивна.

Природна мова в ऑiі широкому значенні трактується як мова, що використовується для спілкування людей. Природною є будь-яка етнічна мова. В онтогенезі виникнення індивідуальної мови починається із звуків, як матеріальних носіїв мовлення людини. Тому рідну, функціонально зручну для дитини мову, яку вона засвоює з народження, можна в цьому сенсі назвати ще й природною мовою.

Успадкована мова - термін, який використовується для номінації мови, яка найчастіше використовується у родині і $\epsilon$ функціонально відмінною рисою від основної мови оточення, поширеної на даній території. За цих обставин у дітей, здебільшого двомовних, успадкована мова $\epsilon$ для них рідною. Інколи успадкована мова не є домінуючою в сім’ї і використовується як прамова лише в розмові 3 бабусею і дідусем. У такій ситуації успадкована мова виступає другою мовою. Поруч із терміном «успадкована мова» вживаються і такі термінологічні словосполучення, як «мова сімейного спадку», «херітажна мова» (Polinsky \& Kagan, 2007; Выренкова, Полинская \& Рахилина, 2014). 
Використовується також термін «домашня мова» (повсякденна мова, мова домашнього вживання, мова сімейного спілкування, мова сімейного кола). Ця функціональна мова найчастіше й більшою мірою використовується в сім’ї й відрізняється від основної мови місцевості, в якій мешкає родина. Як правило носії цих мов двомовні, і домашня мова є для них рідною. Проте в деяких ситуаціях спілкування домашня мова використовується дитиною лише для розмов з окремими членами сім’і, або тільки в певному вузько ситуаційному контексті, являючись таким чином другою мовою (Марушкина \& Рахилина, 2013).

Індивідуальна мова - надбання індивіда, який користується тією або тією мовою (Залевская, 2007); психолінгвістичні одиниці - своєрідні блоки генерації мовлення (Леонтьев, 2003); система концептів і стратегій користування мовою в процесах говоріння й аудіювання (Залевская, 2007). Функції мови індивіда, або індивідуальної мови особистості полягають у забезпеченні іï персоніфікованості. Мова індивіда завжди вирізняється своїм особливим набором і порядком слів, певних видів словоформ і синтаксичних конструкцій, композицій висловлювань. Індивідуальна мова кожної людини лише певною мірою співвідноситься з мовною нормою і має відхилення від неї. Мовлення людини та індивідуальна мова $\epsilon$ відображенням інтелектуального розвитку іï носія. Однак, індивідуальна мова виконує не тільки функції первинно функціональних мов, а й функції вторинно функціональних мов.

Із нейролінгвістичних позицій індивідуальна мова, особливо у білінгва та полілінгва, забезпечується системами нейронних мереж, які локалізуються в різних ділянках мозку. Процедури, необхідні для функціонування індивідуальної мови в людини (рідної, другої, іноземної) як системи базуються, як зазначає Т. Чернігівська (Черниговская, н.д.), на двох складових, як-от: (1) наповнення, зберігання й «витягування» 3 пам'яті деяких організованих списків (слів, морфем, граматичних структур, композицій із різних мов тощо з позначками, наприклад, про частотність); (2) наявність адекватно сформованих правил поводження із цими утвореннями.

Мова внутрішнього мовлення - це особливий феномен, своєрідний вияв функціональної мовленнєво-мовної здібності людини. Її можна розглядати як скорочену форму природної (рідної, другої або іноземної) мови, якою доконуються внутрішньо-мовленнєві фази генеративних процесів. Ці процеси відбуваються «в особливому, прихованому ланцюзі механізму мовлення - попередньому етапі будьякого осмисленого говоріння (чи то голосне, беззвучне або письмове мовлення), а також у людини, яка слухає, що приводить до осмислення сприйнятого повідомлення» (Ушакова, 1985). Внутрішня мова латентно представлена при 
користуванні усіма різновидностями первинно- $\mathrm{i}$ вторинно функціональноцентрованих мов.

Національні мови - мова соціально-історичної спільноти людей, спільна мова нації, яка разом з іншими ознаками (спільність регіональної території, культури, побуту, економічного життя та ін.) характеризує ментальність конкретної нації. Національна мова виявляє постійну тенденцію до етнічної єдності й обов'язково має свою літературну форму існування. Національна мова не завжди є офіційною мовою країни. Національна мова не дорівнює літературній мові, оскільки містить у собі крім кодифікованої мови ще й розмовне мовлення, народні діалекти, жаргони (Ярцева \& Виноградова, 2002).

Регіональні мови використовуються громадянами держави в межах певної іiі території: області, краю, штату, федерального округу, провінції, кантону, муніципалітету, району, села або інших адміністративно встановлених регіонів держави поруч 3 офіційною або державною мовою, які діють на території всієї держави. Офіційний статус регіональної мови закріплений в законодавстві одного або кількох адміністративно-територіальних суб'єктів. У деяких країнах регіональні мови мають одинично й статус офіційних мов.

Мови національних меншин розглядаються як такі, що поширені серед населення країни (окрім державної) i не є мовами іï корінних народів. Як знакові системи й спосіб внутрішньо-групового спілкування громадян, які є представниками національних меншин у поліетнічній країні, мови національних меншин виступають засобом як збереження, так і розвитку ідентичності, виконуючи ментально-культурну функцію. «Framework Convention for the Protection of National Minorities» (1995) та «European Charter for Regional or Minority Languages» (1992) передбачено захист мовних прав, використання рідних мов, гарантування вільного розвитку мов національних меншин та унеможливлення їх зникнення. Представники певної етнічної групи, які мешкають на території держави і є іï громадянами, але не належать до корінного етносу, усвідомлюють себе національною общиною та об'єктивують свою етнічну мову як рідну, рефлексують іiі в якості засобу збереження своїх специфічних рис і своєї культури.

Міжетнічні мови - функціональний тип мови, що використовується для спілкування між носіями різних мов в умовах обмежених соціальних контактів.

До вторинно функиіональних мов відносимо такі види функціональноцентрованих мов, які виконують складніші функції у комунікативно-мовленнєвій активності індивіда порівняно з первинно функціональними мовами. Це, зокрема, мова міжнаціонального спілкування, державна мова, офіційна мова, міжнародна мова, домінантна мова, мова міжнародного спілкування, іноземна мова, штучна мова, друга 
мова. Функції, найскладніші за своїми когнітивними і комунікативними показниками, виконують наступні вторинно функціональні мови: ділова мова, мова професії, мова науки, метамова, мова перекладу, мова спеціальності, професійна мова. Внутрішня мова людини, яка використовується індивідом на імпліцитному внутрішньомовленнєвому (латентному) етапі генерації (говоріння, аудіювання, читання, письмо), інтимно й незримо пов'язана з кожним різновидом функціонально-центрованої мови (Калмикова et al., 2020).

Державна мова - це правовий статус певної етнічної мови; іiі вживання обов'язкове в офіційних документах і загалом у публічних сферах суспільного життя в державі (законодавство, управління, судочинство, освіта тощо). Державна мова постає як мова національності, яка самовизначилася як найпоширеніша в даній полілінгвальній державі й притаманна більшості населення та є для нього рідною. Проте не у всіх громадян державна мова є рідною. Феномен неспівпадання державної і рідної мови у тоталітарних державах і державах, схильних до прояву радикальних націоналістичних тенденцій, викликає закономірні суперечки. Основні протистояння стосуються того, скільки має бути державних мов, яка сфера їх функціонування, в яких співвідношеннях державна мова має бути з іншими етнічними мовами громадян держави та ін. Проте поза межами таких протистоянь залишається питання здатності людини оволодіти і володіти функціями державної мови (в даному випадку як другої чи навіть третьої в мовленнєво-мовному досвіді того чи того громадянина).

Отже, державна мова - це передусім мова конституції країни, а тому вважається, що держави, які не мають кодифікованої конституції, не мають і державної мови. Швейцарія - країна 4-х державних мов (німецька, французька, італійська, ретороманська).

«Офіиійна мова» - поняття споріднене 3 поняттям «державна мова», але не $є$ його синонімом. Проте в деяких авторів ці поняття розглядаються в одному рівноцінному значенні. В «Оксфордському путівнику англійської мови» (McArthur, 1992) офіційну мову (Official Language) держави відносять до мови, яку використовують в уряді (судова система, законодавча влада, адміністрація) (там само: 722). У «Кембриджському словнику» (Cambridge Dictionary) зазначається, що: офіиійна мова - «Мова або одна з мов, яка прийнята урядом краӥни, викладається в школах, використовується в судах тощьо»; офіційна мова як виражальний засіб народу «...не може бути змінена жодним законом» (Muñiz-Arguelles, n.d.). Існують офіційні мови ЕС і офіційні мови ООН.

Отже, відмінності між державною і офіційною мовами лежать передусім у конституційній площині та в їх федеральному або територіальному статусі. Термін «офіційна мова», як правило, відносять не до мови, що використовується 
громадянами, а до уряду країни; це мова, на якій публікуються акти органів міжнародних і наднаціональних організацій, і які визнаються автентичними; мова, яка може офіційно використовуватися в державних органах або органах місцевого самоврядування поруч із державною і на якій громадяни мають право звертатися у відповідні органи.

У Канаді англійська і французька мови визнані Конституцією Канади в якості «офіційних». Всі закони на федеральному рівні зобов'язані прийматися як англійською, так і французькою мовами. Це ж стосується і послуг федеральних органів: вони мають бути доступні обома мовами. В Канаді підкреслюється ऑii мультикультуралізм і зростає кількість мов, які підтримуються державою, місцевими адміністраціями та приватними ініціативами.

Суперечки про те, чи потрібна англійська мова в якості єдиної державної мови, продовжуються в США протягом багатьох років, проте відповіді на це запитання не знайдено.

У деяких країнах у відповідності з їхніми Конституціями допускається паралельне вживання термінів державна мова та офіційна мова (Білорусь, Канада, Фінляндія, Швейцарія). В Україні згідно з Конституцією допускається вживання лише терміна «державна мова».

Мова міжнаціонального спілкування - це мова, яка використовується як засіб спілкування представниками різних національностей у межах однієї країни. Це мовапосередник у багатонаціональній країні для взаєморозуміння i взаємодії. Мовою міжнаціонального спілкування здебільшого виступає або державна, або офіційна мова.

Міжнародна мова - використовується для комунікації значної кількості людей в усьому світі («мови світового значення» - синонімічна назва). В сучасному світі виділяється до 10 міжнародних мов. Міжнародний статус мають: англійська, китайська, іспанська, французька, арабська, російська, португальська, німецька. Межі між міжнародною мовою й мовою міжнародного спілкування досить розмиті. Під міжнародною мовою може матися на увазі й штучна мова. Ознаками міжнародної мови вважаються такі: (1) велика кількість носіїв мови вважають ії рідною; (2) велика кількість комунікантів володіють нею як іноземною або другою; (3) цією мовою говорять у багатьох країнах, на кількох континентах, у різних культурах тощо; (4) у різних країнах вивчається в школі як іноземна; (5) використовується як офіційна мова міжнародними організаціями.

Мова міжнародного спілкування, міжнародна світова мова - мова, яку застосовують для спілкування на міжнародному рівні, вивчають як другу або третю, четверту і т.д. мову, яка здебільшого повністю відсутня в природному мовному середовищі і засвоюється лише в процесі навчання. Мовою міжнародного спілкування вважається та, яка $є$ однією з найпопулярніших мов у світі; якою 
говорять мільйони людей в різних країнах і щорічно багато хто починають вивчати їі, що пов’язане з тенденцією сучасного світу до глобалізації й відповідно до визначення глобальної мови, яка буде пов'язувати людей в усьому світі незалежно від того, чим вони займаються і яка мова у них є рідною.

Ділова мова - це різновид літературної мови, що має свої засоби вираження, способи номінації й своєрідні засоби виразності. Це не канцеляризми і не штампи. Дотримання норм ділової мови грунтується на об’єктивно створеній традиції побудови писемного й усного мовлення відповідно до змісту, що виражається, та обставин. Будь-який вираз у діловій мові базується на традиції, на усталених формах і манерах, наприклад, написання заяв та інших ділових паперів. Така усталена форма $\epsilon$ доцільною і виправданою в офіційно-діловому спілкуванні. Ділова мова цілком рівноправна з іншими різновидами літературної мови та іншими стилями, відіграючи важливу роль у розвитку літературних мов різних етносів і культур. Ділова мова представлена двома різновидами: (1) офіційно-документальна мова (мова дипломатії, мова законів, указів, постанов); (2) ужитково-ділова мова (службова переписка, ділові папери у сфері правових відносин і управління).

Мова науки представлена системою понять, знаків, символів. Створюється і використовується тією чи тією галуззю наукового пізнання для отримання, вираження, опрацювання, збереження і застосування знань. У якості спеціальної мови конкретних наук використовується певний фрагмент природної мови, збагаченої додатковими знаками і символами. Мова науки відрізняється точністю своїх понять, навіть «житейські» (Выготский, 2000) поняття отримують завдяки мові науки значно повніше і точніше, й навіть парадоксальне з огляду на здоровий глузд значення. У мові науки вживаються як поняття природної мови, так і терміни, які відносяться до абстрактних, ідеалізованих об’єктів, до об'єктів, в яких виявляються їх властивості і зв’язки. Мова науки виступає передусім знаряддям пізнання певної області явищ. Ї̈̈ специфіка визначається як особливостями галузі, що вивчається, так і методами їі пізнання. Мова науки здебільшого позбавлена багатозначності термінів, розпливчатості, невизначеності їх змісту, подвійного смислу виразів, семантичної замкнутості та ін. Мова науки, як специфічна знакова система, слугує матеріальним вираженням отриманих результатів пізнавальної діяльності.

Нерідна мова може бути трьох видів: (1) друга, (2) домінантна й (3) іноземна.

Друга мова - це мова, що використовується в тій спільноті, у якій розвивається дитина із нацменшин, навчаючись в інституціональних закладах; друга мова завжди наявна в мовному середовищі (Леонтьев, 2003). 3 огляду на функціонування друга мова як один із проявів функціональної мовленнєво-мовної здатності має певні відмінності від рідної мови. Вона відрізняється своєю орієнтувальною ланкою й 
операційним складом висловлювання (мовленнєвої дії) (Леонтьев, 2003: 220). Друга мова, на його думку, - це мова, яка засвоюється або під час спеціального навчання, або в стихійному мовному оточенні в більш дорослому віці (там само).

Домінантна мова - це в більшості випадків друга або третя в житті дитини мова. Її функції полягають у тому, щоб у певний період іiі вікового і взагалі психічного розвитку найтісніше пов'язуватися із становленням психічних процесів, станів і властивостей іiі особистості, узагалі із психічним розвитком, особливо мовленням і мисленням (Леонтьев, 2003). У дітей з різних країн, в яких рідною мовою $\epsilon$ мова національних меншин, другою мовою стає домінантна (яка одночасно є або офіційною, або державною мовою). Як вже зазначалося з посиланням на О. Козінцева (Козинцев, 2004), друга мова не перетинається в корі головного мозку 3 першою мовою, а локалізується або в різних ділянках однієї півкулі, або в різних півкулях.

Іноземна мова - це мова, яка відсутня в конкретній мовній спільноті: носіїв цієї мови в мовному середовищі немає або практично немає. Для іiі освоєння в інституційних закладах створюється штучне мовне середовище (Леонтьев, 2003). Її функції полягають у розширенні меж спілкування, удосконаленні генеративної системи індивідів. Щодо іноземної мови, то вона, як правило, не $\epsilon$ близькоспорідненою мовою, тому засвоюється за іншими психолінгвістичними механізмами, ніж споріднені мови. Вона в окремих випадках стає третьою мовою й потребує не тільки виформовування нової системи нейронних мереж в корі головного мозку, а й значної перебудови усталеної діяльності нейролінгвістичних i психодинамічних процесів.

У контрастних чи в синонімічних відношеннях знаходяться такі види вторинно функціональних мов, як індивідуальна мова й літературна мова?

Літературна мова - це кодифіковані мовні одиниці, співвіднесені з мовним стандартом (тобто з об'єктивно існуючою в «соціальній пам'яті» народу мовною системою та мовною нормою (Леонтьев, 2003)). Вона безпосередньо корелює 3 державною або офіційною мовою.

Метамова - струнка система дозволяючих і забороняючих (прескриптивних) стабільних приписів, що діють у синхронних рамках культури; система конструктів і правил їх комбінування (Залевская, 2007). Функція метамови - структурування та удосконалення функціональної мовленнємовної здатності людини. Існує: (а) первинна метамова (природна); іiі функції - створення продуктів емпіричних спостережень i дотеоретичних мимовільних мовних узагальнень, потрібних для реалізації генеративних процесів. Первинна метамова характерна навіть і для дошкільників; (b) вторинна метамова; іiі функції - опис об'єктів лінгвістичних досліджень, результат пізнання й розуміння лінгвістичних явищ; метамова - це своєрідні психологічні 
(когнітивні) одиниці, компоненти нашого вивченого знання про свою мову (Леонтьев, 2003). Ці знання на рівні первинної метамови - неусвідомлені й ненавмисні, а на рівні вторинної метамови - усвідомлені, довільні й навмисні (Калмикова \& Новікова, 2018).

Мова перекладу в широкому психолінгвістичному значенні - це різновид вияву мовленнємовної здатності людини, за допомогою якої здійснюється переклад, або їі перекладна мова. Одночасно використовуються терміни «мова-реципієнт», «моварецептор» - як антоніми поняття «вихідна мова» - мова, 3 якої здійснюється переклад. Функції мови перекладу - передавання тих значимих елементів «вихідної мови», які відсутні в ній, компенсування їх через кальки, слова-запозичення, неологізми, семантичні зрушення.

Важливими сучасними проблемами в психолінгвістиці мови перекладу є кілька проблем функціонального походження: «Як змінення мов (вихідної мови і мовиреципієнта) впливає на переклад тексту?», «Чи повинен переклад змінюватися відповідно до змінення мов?», «Чи потрібні пере-переклади?», «Якою мірою перекладач має намагатися імітувати мову епохи, 3 якої походить текст?» (Информационно-аналитический портал).

Професійна мова здебільшого розглядається як «один із видів соціального діалекту», «компонент загальної мовної системи», в якій «існує кодифікована i некодифікована лексика» (Малюга, 2011). Соціальний діалект тлумачиться як різновид мови, на якій говорять певні соціальні групи населення. Професійна мова як вияв мовленнємовної здібності виступає додатковим засобом спілкування лише у членів окремих професійних колективів, але не народу усієї країни і не всього регіону. Функції професійної мови як функціональної мовної здатності фахівців різних соціономічних профілів, пов'язані 3 вирішенням фахових завдань, які потребують використання особливих, призначених для використання у професійних спільнотах, вербальних засобів.

Професійна мова, будучи частиною вторинно функціональної мовної здатності людини, забезпечує ефективність спілкування співтовариства спеціалістів, які займаються одним видом діяльності.

Мова спеціальності пов'язана з таким аспектом діяльності як навчання мови, що забезпечує загальнонаукове і професійне спілкування при отриманні майбутнім фахівцем кваліфікації (професії) в освітній установі мовою, що вивчається. Відтак, мова спеціальності стає його індивідуальною мовою, складовою його функціональної мовної здібності. 


\section{Висновки \\ Conclusions}

Отже, незалежно від конкретно взятої етнічної мови чинником, який об’єднує всі охарактеризовані мови в єдину функціональну систему є здатність людини генерувати мовлення (екстерналізувати й інтерналізувати), використовуючи її в тій чи тій функції, зокрема функції домінантної мови, рідної мови, метамови, мови науки, міжнародної мови та ін.

\section{Література \\ References}

Cambridge Dictionary. (n.d.). URL https://dictionary.cambridge.org/us/dictionary/english/officiallanguage

European Charter for Regional or Minority Languages. (1992). URL https://www.coe.int/en/web/conventions/search-on-treaties//conventions/treaty/148/declarations

Framework Convention for the Protection of National Minorities. (1995). URL https://rm.coe.int/16800c10cf

McArthur, T. (Ed.). (1992). The Oxford Companion to the English Language. Oxford - New York: Oxford University Press.

Muñiz-Arguelles, Luis. (n.d.) The Status of Languages in Puerto Rico. URL http://munizarguelles.com/resources/The+status+of+languages+in+Puerto+Rico.pdf

Polinsky, M., \& Kagan, O. (2007). Heritage languages: In the 'wild' and in the classroom. Language and Linguistic Compass, 1(5), 368-1395. https://doi.org/10.1111/j.1749818X.2007.00022.X

Вахтин, Н.Б., \& Головко, Е.В. (2004). Социолингвистика и соииология языков. Санкт-Петербург.

Выготский, Л.С. (2000). Психология. Москва : Изд-во ЭКСМО-Пресс.

Выренкова, А.С., Полинская, М.С., \& Рахилина, Е.В. (2014). Грамматика ошибок и грамматика конструкций: «эритажный» («унаследованный») русский язык. Bonpocbl языкознания, 3, 3-19.

Залевская, А.А. (2007). Введение в психолингвистику. (2-е изд.). Москва: Российский государственный гумманитарный университет.

Информационно-аналитический портал. (n.d.). URL https://polit.ru/

Калмикова, Л., \& Новікова, Г. (2018). Психолінгвістичні феномени «знання мови» і «знання про мову»: проблеми співвідношення й функціонування в мовленні дітей. Psycholinguistics, 23(1), 99-118. https://doi.org/10.5281/zenodo.1211606

Калмикова, Л., Харченко, Н., Волженцева, І., Калмиков, Г., \& Мисан, І. (2020). Актуалізація проблематики внутрішнього мовлення в психолінгвістиці комунікації: результати систематичного огляду і метааналізу. Psycholinguistics, 28(1), 83-148. https://doi.org/10.31470/2309-1797-2020-28-1-83-148 
Калмикова, Л.О. (2018). Що потрібно знати вчителю про знання у дітей мови та метамови. Початкова школа, 7, 54-58.

Калмикова, Л.О., Харченко, Н.В., \& Мисан, І.В. (2021). «Я-мова» і.е. «Індивідуальна мова»: проблема функціональної генералізації. Psycholinguistics, 29 (1), 59-99. https://doi.org/10.31470/2309-1797-2021-29-1-59-99

Козинцев, А.Г. (2004). Происхождение языка: новые факты и теории. Теоретические проблемы языкознания (с. 35-50). Санкт-Петербург : Филологический факультет.

Леонтьев, А.А. (2003). Основы психолингвистики. (3-е изд.). Москва: Смысл; СПб.: Лань.

Малюга, Е.Н. (2011). Основные характеристики профессионального языка. Вестник Самарского государственного университета, 1/2(82), 133-138.

Марушкина, А.С., \& Рахилина, Е.В. (2015). Корпусные исследования особенностей речи нестандартных говорящих («херитажный» русский). Acta linguistica petropolitana. Труды Института лингвистических исследований, ХI(1), 621-638.

Ушакова, Т.Н. (1985). Проблема внутренней речи. Вопросы психологии, 2, 39-51.

Ушакова, Т.Н. (2004). Речь: Истоки и принциипь развития. Москва: Пер Сэ.

Цейтлин, С.Н. (2000). Язык и ребёнок: Лингвистика детской речи. Москва: ВЛАДОС.

Черниговская, T.B. (н.д.). Психо- $и$ нейролингвистика. URL http://window.edu.ru/resource/503/38503/files/spr0000015.pdf

Ярцева, В.Н., \& Виноградова, В.А. (Ред.). (2002). Лингвистический энциклопедический словарь. (2-е изд.). Москва : Большая Российская энциклопедия. 